\title{
THE INFLUENCE OF THE COVID-19 PANDEMIC ON THE ENTREPRENEURIAL INTENTION OF YOUNG PEOPLE
}

\author{
Ana-Maria Badea \\ Bucharest University of Economic Studies, Romania, badea.anamaria98@yahoo.com
}

\begin{abstract}
COVID-19 is an extremely infectious disease and a danger to human health, causing deaths worldwide. The aim of the paper was to identify how the crisis caused by the COVID-19 pandemic negatively influenced the entrepreneurial intentions of young people. The study starts from the hypotheses that entrepreneurial intentions among young people have decreased due to the pandemic and that the existence of entrepreneurs in the family or circle of friends can positively influence young people. A review of the literature has created an overview of the importance of entrepreneurship in a country's economy and how the pandemic affected the entrepreneurs. To collect data, a questionnaire was distributed among young people between 16 and 35 years old. Following the evaluation of the respondents' answers, the two hypotheses were validated. It was found that young people who already have their own business also have relatives or friends who are entrepreneurs, who influenced them to follow the path of entrepreneurship. The pandemic has negatively affected young people, as before March 2020, $35.6 \%$ of young people wanted to start their own business, now $24.4 \%$ are undecided due to restrictions and uncertainty, and $1.6 \%$ gave up the idea setting up a business. Thus, we can conclude that the pandemic has caused disruptions to the economy and entrepreneurship, raising many challenges for current and future businesses.
\end{abstract}

Keywords:

COVID-19, young people, entrepreneurship, economy, business

JEL Classification: L20, L26, L29

DOI: $10.24818 / \mathrm{CTS} / 3 / 2021 / 1.06$

\section{Introduction}

Starting a business is not easy, but neither is maintaining it in the current context. Entrepreneurs are a vital source for maintaining a country's economy. They manage to stimulate the economy by introducing innovative technologies, services, products and at the same time, provide jobs, lowering the unemployment rate.

The problems facing small businesses today have evolved from a health crisis to an economic one. Entrepreneurs strive to survive both crises with available resources. This image discourages young people who wanted their own business before the COVID-19 pandemic broke out.

The aim of this paper is to explore the extent to which the crisis caused by the COVID-19 pandemic has negatively influenced the entrepreneurial intentions of young people. The study examined several factors that lead to uncertainty and indecision on the part of young people when it comes to starting a business in the current context. The paper begins with a review of the literature, highlighting the importance of entrepreneurship to support the economy and how the coronavirus pandemic has affected small businesses and entrepreneurs.

The second part of the paper presents the objectives, hypotheses and research methodology, followed by an interpretation of the results after the distribution of a questionnaire among young people aged between 16 and 35 years. The last part of the paper presents the conclusions and recommendations for future and current entrepreneurs.

\section{Analysis of the specialized scientific literature}

Entrepreneurship is one of the main factors in supporting a capitalist economy and the main source of job creation. The entrepreneur is the individual who recognizes the potential of a particular field or discovers the opportunity to bring something new to the market (a new product or service), and who uses various means to develop the concept designed to bring satisfaction to the market. 
Entrepreneurship is a creative human process, one that mobilizes resources at a higher level of productivity. It involves the individual's willingness to take on responsibilities and mentally the ability to accomplish the task from idea to implementation. Another component of entrepreneurship is to identify opportunities where other people find only chaos, contradictions or confusion (Toma, Grigore, and Marinescu, 2013).

Regarding the role that entrepreneurship plays in the development of the economy, many theories in the literature support entrepreneurial approaches to the development of a country, because it stimulates competition by increasing the number of enterprises, so there is diversity in that market. The entrepreneur encourages other individuals to develop new companies, being a cumulative phenomenon. Entrepreneurs identify new opportunities for innovation, which leads to the facilitation of knowledge exchange, with new knowledge being passed on from the point of origin of innovation to other organizations. Entrepreneurship generates diversity and variety that influence economic growth. Unemployment is a big problem for most countries, and entrepreneurs play an important role in reducing it, because it provides jobs, and over time as the company grows, it will need more and more human resources.

Entrepreneurship helps balanced regional development, because the indirect beneficiaries are also public transport, health, education and entertainment. Thus, small businesses generate more activities and create a multiplier effect in the economy (Dhaliwal, 2016). Entrepreneurship increases the growth of gross domestic product and per capita income because an entrepreneur explores opportunities, encourages the efficient mobilization of capital resources, brings new products and services by developing markets for economic growth. Entrepreneurship also increases people's living standards, brings to market a variety of innovative products and services that make everyday life easier, being high quality and affordable. Another important ingredient for the development of the economy is represented by the country's foreign trade, through goods created and distributed anywhere in the world, the entrepreneur offers economic independence and development of the country where he exports his products (Dhaliwal, 2016).

Usually, individuals have to choose between unemployment, self-employment and employment (Verheul 2010). Entrepreneurial intent involves an individual decision to move from unemployment or a private job to a self-employed job. At present, it is generally accepted that education is vital for the creation of entrepreneurs and an entrepreneurial community. The decision to be self-employed is considered voluntary, conscious, and intentionally planned (Krueger, Reilly and Carsrud, 2000).

One of the big global problems is the high level of youth unemployment. Entrepreneurship is considered a tool that generates income among young people, being a way to integrate them into the labour market and overcome poverty. Entrepreneurial intentions are often guided by economic necessity when there is no other alternative for generating income or earning a living. A study by GEM (Global Entrepreneurship Monitor), says that young people with a precarious financial situation and low level of social security are attracted to starting a business (GEM, 2014). Intentions in the fields of entrepreneurship are defined as the desire of an individual to undertake an entrepreneurial activity and start a new business at some point in the future (Thompson, 2009).

In the literature, there is an increased interest in improving the degree of knowledge of variables that favour entrepreneurship in a regional context. The phenomenon of globalization and the development of information and communication technology have accentuated this phenomenon because they make entrepreneurship an international phenomenon, questioning the influence of regional and national frameworks.

There are two main lines of research on the factors that favour entrepreneurship (Martínez-González, et al., 2019). The first is the contextual approach which says that entrepreneurship is influenced by education, culture and access to financial resources. The second is that of human capital, where research focuses on motivation, values and self-efficacy.

Some researchers have analysed the determinants of entrepreneurial intentions from the perspective of the dichotomy driven by necessity/opportunity determined by the anchoring effect (Jamali, 2009), motivation and barriers (Fatoki and Patswawairi, 2012), personality traits (Canedo et al., 2014), theory of planned behavior (Iakovleva, Kolvereid and Ute, 2011) and Shapero's theory of entrepreneurial event (Solesvik et. al., 2012). 
Unfortunately, we are currently facing a global crisis created by the COVID-19 pandemic, due to which a lot of businesses have ended or plans to open a business have been destroyed. COVID-19 is a virus also known as Coronavirus that appeared at the end of 2019. Unfortunately, the drastic measures needed to prevent the spread of COVID-19 require several pieces of legislation, actions that prohibit the normal functioning of society. These include wearing face masks, social distancing, staying home and finally blocking all movements. Consequently, the normal business activities cannot be carried out by the fear that the disease will be spread. Most businessmen have had to close their stores, resulting in an unprecedented multitude of problems. Closing the store means losing business and therefore losing revenue. This triggers a domino, led by employment and employee welfare (Ahmad Al-Fadly, 2020).

The majority of the IT sector made a profit from operations in the first quarter of the financial year 2020. This year, most companies in the non-IT sector are facing losses due to the COVID-19 pandemic and the economic downturn (Zacks Equity, 2020). There is a change in the attitude of consumers in using opportunities in the online environment (Celic et al., 2018). In China, for example, while consumer demand is low, people have dramatically changed their consumption habits, focusing on online shopping for all kinds of goods, including food delivery. Companies should invest in online as part of their efforts; ensuring the quality of goods sold online (Craven et al., 2020). As a result of this change in customer purchasing preferences, the business model will be strongly influenced, the distribution channels being one of the most affected dimensions (Pop, 2020).

It is a crucial time for entrepreneurs, some businesses have flourished through innovation, others have failed. Entrepreneurs have found innovative ways to add value to society, they have found solutions to the problems caused by the pandemic. Businesses in the cosmetics industry have focused on the manufacture of disinfectant for health. Fashion workshops have created personal protective equipment, such as gowns and masks. Traditional stores have moved online and created new jobs. Entrepreneurs are people who recognize and act on opportunities to promote positive social change.

\section{Methodology}

The present study focuses on how the COVID-19 pandemic influenced the entrepreneurial intentions of young people. As a research and data collection tool, a questionnaire with 19 questions was implemented, which wanted to identify the influence of the current pandemic crisis on entrepreneurial intention. Various types of questions were asked, pre-coded with given answers and questions with scale answers, to identify various issues.

The questionnaire is structured in three parts. The first seven questions provide information about entrepreneurial intentions and the type of business you want. The next seven are about how the COVID19 pandemic affects young people in starting a business. The last part of the questionnaire contains socio-demographic questions in order to be able to classify the respondents. The data collected were centralized in a database which resulted in a sample of 250 respondents.

The objectives of the research were to observe the trends regarding the entrepreneurial initiative of young people during the crisis created by the COVID-19 virus and to understand the main factors that influenced it. The research starts from the hypotheses that the pandemic caused by the COVID-19 virus has negatively influenced the entrepreneurial intentions of young people and that the existence of entrepreneurs in the family or circle of friends can mitigate the negative influence of the pandemic.

\section{Results}

In the last year, a lot of businesses have failed due to the crisis caused by the COVID-19 virus, others have flourished through innovation or people's need for their products/services. The failure of some because of the virus discourages others from finding opportunities.

Of the people who answered the questionnaire, $46.6 \%$ are employed and 53.3\% do not work. Of those who have a job and those who are not employed, $35.6 \%$ intended to open a business before March 2020, $39.6 \%$ did not want a business, $20.8 \%$ are undecided, $2 \%$ already had their own business and $2 \%$ intended to enter the family business (Figure 1). Thus, we can observe from these results a great interest for the entrepreneurial field, the young people being more and more attracted to be the owners of a business, than employees. Entrepreneurial desire can start from the desire for a flexible program and financial satisfaction. 
Did you intend to open a business before the pandemic (March 2020)?

I intended to get into the family business

I already had a business

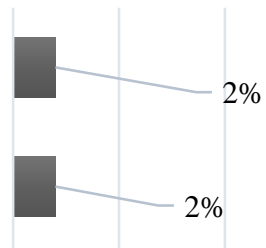

I was indecisive

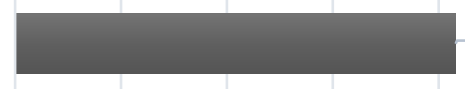

$20,80 \%$

No

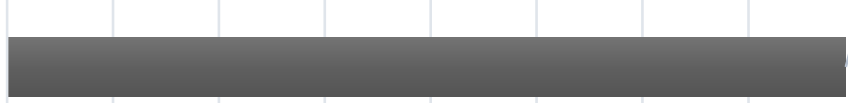

Yes

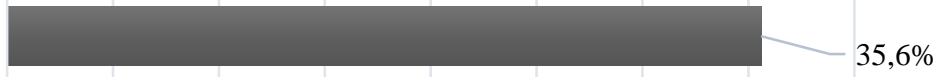

Fig. no. 1: Entrepreneurship intention of respondents before March 2020

Source: Own processing following the data collected

Currently, one year after the start of the pandemic, entrepreneurial intentions have changed, most of the respondents, $44.4 \%$ are undecided about starting a business, $29.2 \%$ do not want to start a business, $18 \%$ want to start a business right now, and $6.4 \%$ have already started their own business before or during the pandemic and $2 \%$ are part of the family business (Figure 2). We can see a decrease in the entrepreneurial intentions of young people, $44.4 \%$ being undecided due to the current pandemic situation, but there is also a significant percentage of young people who have opened their own business in the pandemic. From the results presented we can see a decrease in entrepreneurial intentions among young people.

Assessing the entrepreneurial intentions of young people before the COVID-19 pandemic and the current entrepreneurial intentions, it turned out that $1.6 \%$ of respondents who wanted to start a business before the pandemic now no longer want to, $4.4 \%$ opened their own business, and $24.4 \%$ are undecided due to the pandemic. Following the results, we can see the decrease of entrepreneurial interest after one year from the beginning of the pandemic.

\section{Currently, a year after the start of the pandemic, do you intend to open a business?}

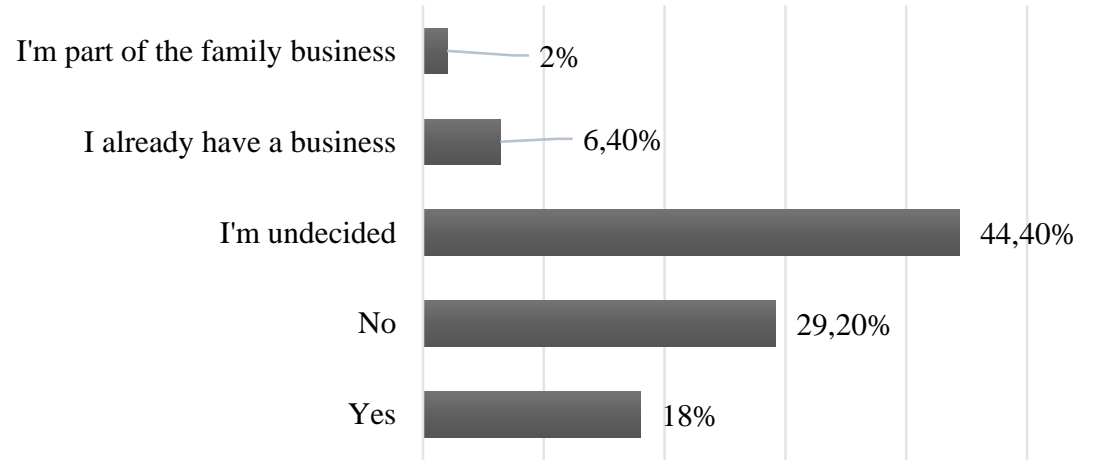

Fig. no. 2: Entrepreneurial intention of respondents during the COVID-19 pandemic Source: Own processing following the data collected

The entrepreneurial intentions of an individual can be accentuated by the models he has around him, this means relatives or friends, who have set up their own business. Among the respondents who answered the questionnaire, $42.8 \%$ have family members with their own business while $57.2 \%$ do not. 
Regarding the circle of friends, $67.2 \%$ of the respondents have friends who have already set up their own business and $32.8 \%$ said that they do not have friends who own their own business.

Correlating the answers "I already have a business" to the question "Now, a year after the start of the pandemic, do you intend to open a business?" and the answer "yes" to the question "Did you have someone in the family with their own business?", resulted in a percentage of $1.2 \%$ of respondents who have their own business and were probably influenced by relatives to open it. We made the same correlation for the question "Are there entrepreneurs in your circle of acquaintances (friends)?", Deriving a percentage of $5.2 \%$. Thus, it results in a percentage of $6.4 \%$, the same as the number of respondents who already own a business. From here we understand that the people around us who own their own business influence us to a great extent and we become entrepreneurs.

Given the impact that the COVID-19 pandemic had on some economic sectors, we wanted to identify among respondents whether they were discouraged by some industries and what they want to focus on in starting a business. Regarding the economic sector in which most respondents want to open a business, $21.2 \%$ are aimed at trade, being a sector that has high revenues during the pandemic, followed surprisingly by tourism with a percentage of $14 \%$ (Figure 3 ).

\section{If you were to open a business, in which economic sector do you want to work?}

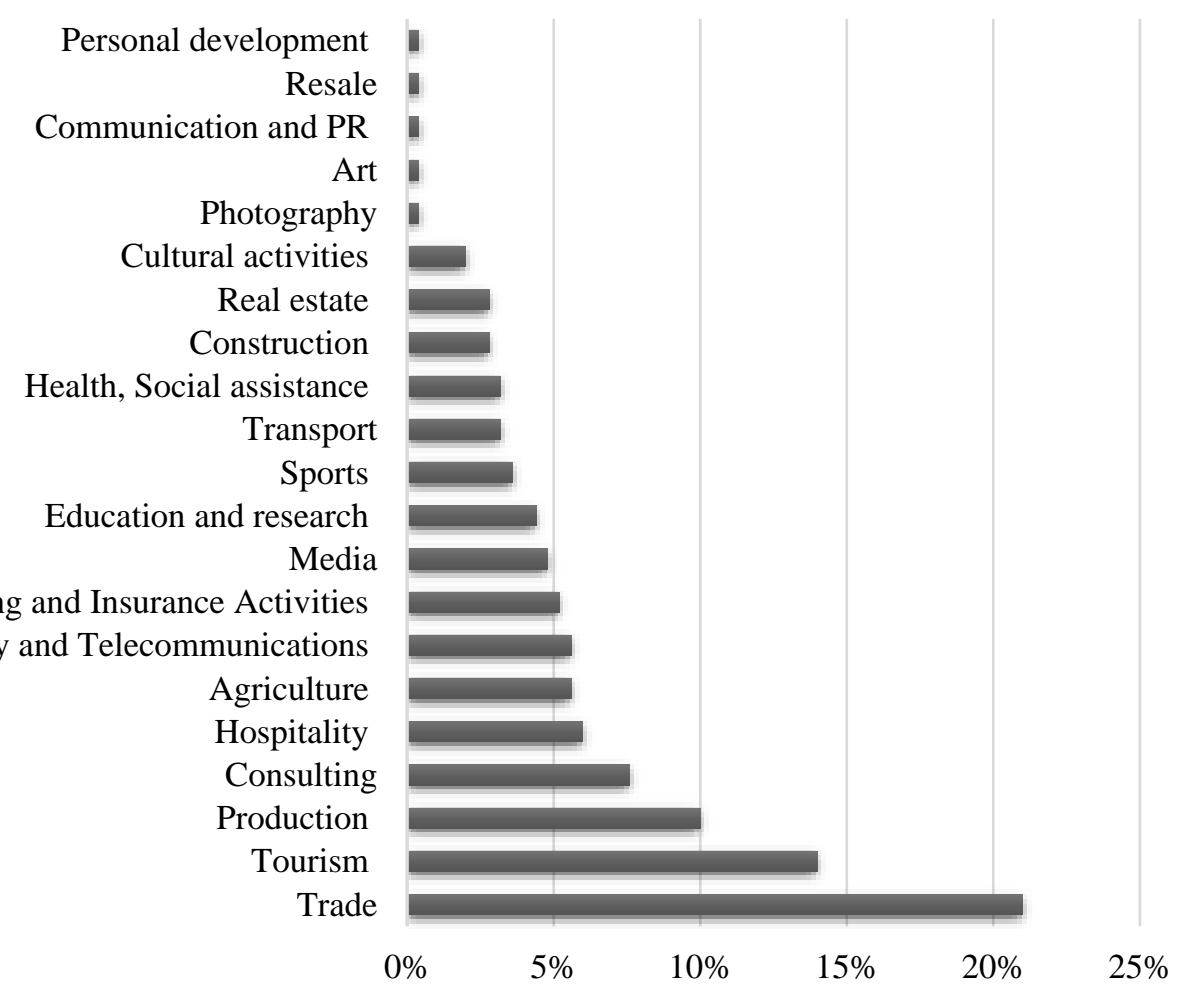

Fig. no. 3: Economic sectors in which respondents would open a business Source: Own processing following the data collected

As can be seen in Figure 3, in addition to trade and tourism, there are other economic sectors with great entrepreneurial potential such as: production (10\%), consulting (7.6\%), hospitality $(6 \%)$, agriculture (5.6\%), information technology and telecommunications (5.6\%), financial, banking and insurance activities (5.2\%), media (4.8\%), education and research (4.4\%), sports (3.6\%), transport (3.2\%), health, social assistance $(3.2 \%)$, construction $(2.8 \%)$, real estate $(2.8 \%)$, cultural activities $(2 \%)$, photography $(0.4 \%)$, art $(0.4 \%)$, communication and PR $(0.4 \%)$, resale $(0.4 \%)$ and personal development $(0.4 \%)$ (Fig. 3 ). From the above results (Figure 3), we can see a great interest in businesses that have great potential for development in the online environment. 
Regarding the way of doing business, most respondents, $63.4 \%$ want their entrepreneurial activity to take place physically, as opposed to $36.6 \%$ who want a business online. Even though at the moment our professional activity has moved to the online environment and is sometimes more convenient, we can notice the desire of people for face-to-face interaction.

Asked if the current economic situation discourages them from starting a business, $68 \%$ of respondents said yes and $32 \%$ said no. From here we can see the entrepreneurial discouragement transmitted by the crisis caused by the COVID-19 pandemic.

Analysing the perception of the last year of the respondents regarding the opening of a business, it shows that for $52 \%$ it deteriorated, for $32.4 \%$ it remained unchanged, $3.2 \%$ of the respondents say that they improved their perception and $12.4 \%$ did not can be pronounced.

Evaluating how respondents see this period for starting a business, $34.5 \%$ said they delay plans to open a business, $24.6 \%$ said it is a barrier to future business projects, $23.4 \%$ say it is an opportunity to learning, $7.9 \%$ of them said that it is a failure in the entrepreneurial approach, $6.7 \%$ cannot pronounce and $2.8 \%$ believe that the pandemic has no impact on future business projects (Figure 4 ). Only $2.8 \%$ of respondents do not see the pandemic as a threat to start a business, the rest of the respondents being affected. Young people have no experience in crisis management, and this pandemic has dramatically changed their perception of starting a business.

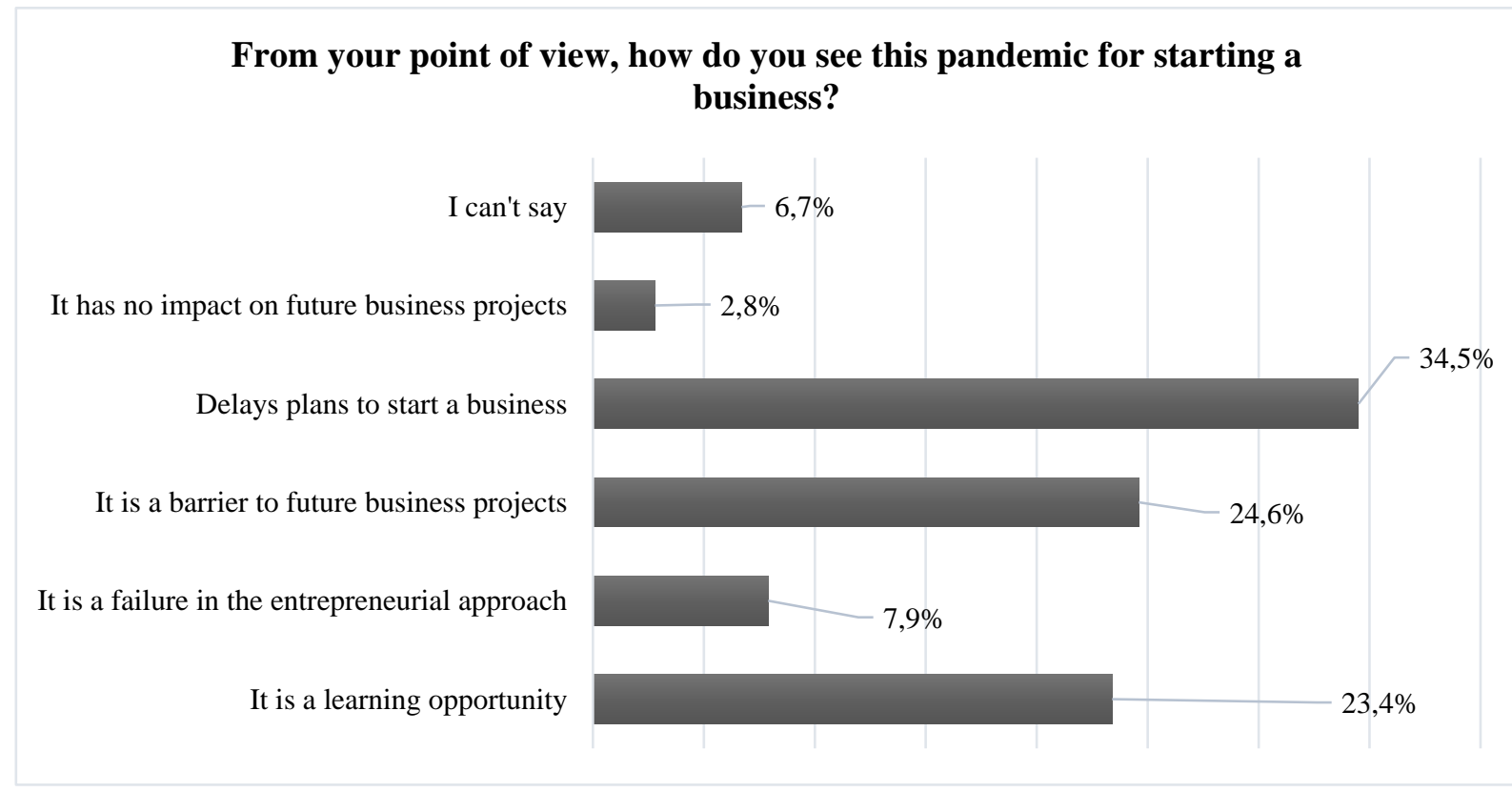

Fig. no. 4: Respondents' perception of the pandemic for starting a business.

Source: Own processing following the data collected

Regarding the barriers encountered by respondents in starting a business, 58.8\% of them say that they do not have sufficient financial resources, $22.6 \%$ do not have sufficient knowledge about the field in which they want their business, $8.9 \%$ say that they cannot rise to the level of competitors, $6.6 \%$ do not have access to the market, and the rest of the respondents face government restrictions, other professional activities or indecision.

Regarding the obstacles encountered in setting up a business during the Covid-19 pandemic, we have the following results:

\section{a) Low chances of making a profit}

Regarding this indicator, $4 \%$ of respondents said that it represents an exceedingly small obstacle, $16.4 \%$ said that to a small extent, $14.4 \%$ are neutral, for $44.4 \%$ it is a major obstacle measure and $20.8 \%$ say that for them it is an obstacle to a very large extent. 


\section{b) High level of stress (uncertainty, restrictions, decreased income)}

Regarding the level of stress, $2.4 \%$ do not consider it a very small obstacle, $24 \%$ say it is a small obstacle, $12 \%$ are neutral, for $37.6 \%$ stress is a large obstacle and for $24 \%$ to a very large extent.

\section{c) Greater responsibilities (compliance with the hygiene rules imposed)}

During this period, the responsibility of entrepreneurs is increased, because the spread of the COVID19 virus must be limited. Thus, for $5.6 \%$ responsibility is a very small obstacle, $27.2 \%$ answered that to a very small extent, $15.2 \%$ are neutral, $32.4 \%$ participants in the study say that it is a major obstacle, and $19.6 \%$ believe that it is a very large obstacle.

\section{d) Higher risk of bankruptcy}

Regarding the high risk of bankruptcy, $2 \%$ of respondents consider it a very small obstacle, $6.4 \%$ to a small extent, $15.6 \%$ are neutral, $37.6 \%$ say it is a largely obstacle, and $38.4 \%$ to a large extent.

The above results show that there is a high level of stress during this period for young people who want to start a business, being concerned about the low chances of profit, high risk of bankruptcy and high responsibility for protecting the health of others.

Regarding the facilities that a young entrepreneur must have during this period, $39.3 \%$ believe that there should be more financing projects, $26.1 \%$ consider that a more flexible legislation for entrepreneurs at the beginning of the road is suitable to them, $15.6 \%$ believe that taxes should be reduced, $14 \%$ need courses for entrepreneurial and managerial education, and 5.1\% feel the need for access to the activities of entrepreneurial companies and associations of entrepreneurs (Figure 5). From these results we can conclude that young people do not have enough access to funding programs for young entrepreneurs, other issues being related to taxes and legislation, which should facilitate the development of entrepreneurship in the country. Also, young people need access to education through managerial training courses.

\section{Which of the following facilities do you consider most important for a young entrepreneur at the moment?}

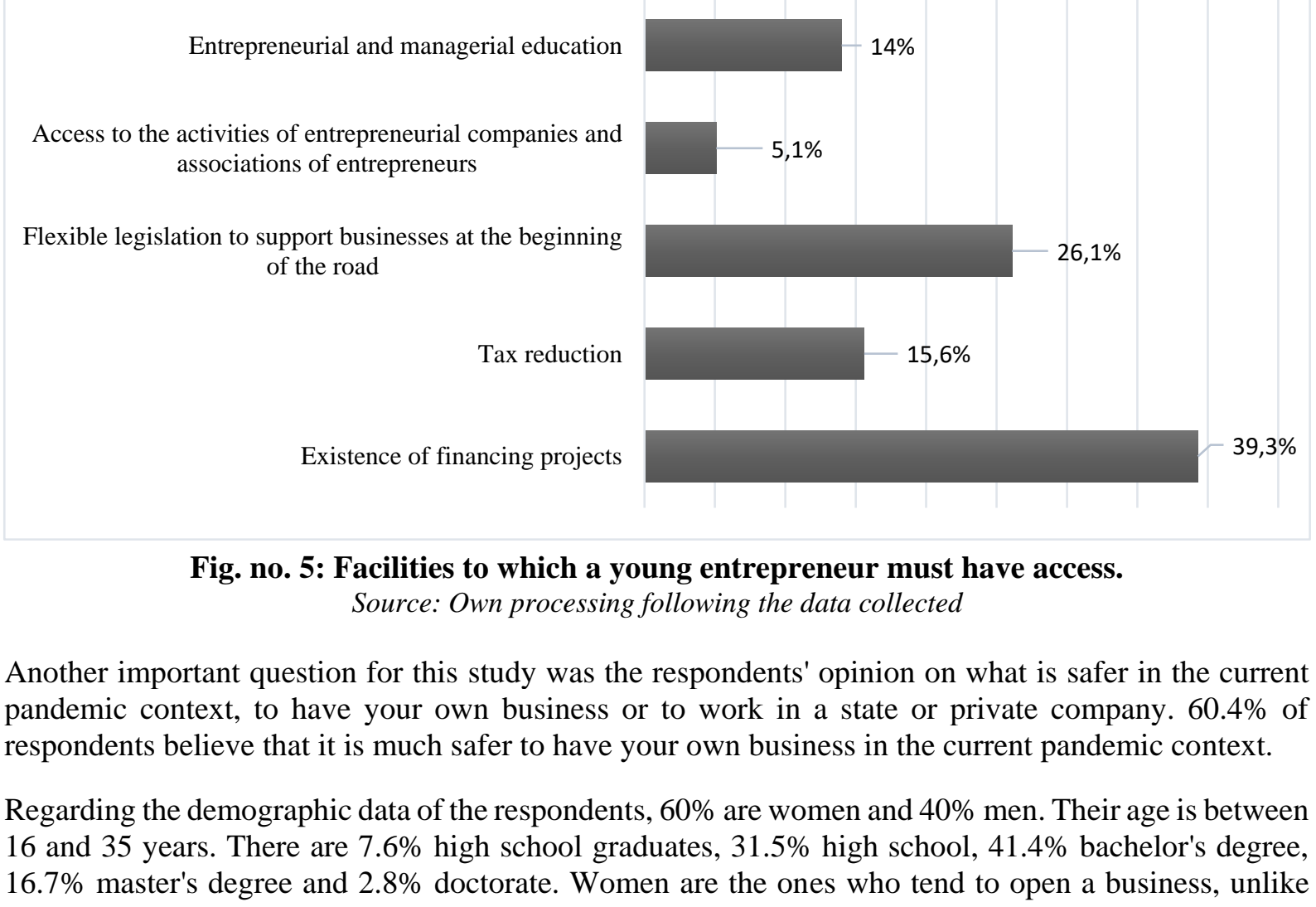


men. Also, studies significantly influence young people, with bachelor's and master's graduates being the most interested in starting a business.

Referring to the region from which they come, $48.4 \%$ are from Muntenia, 9.6\% Oltenia, 7.2\% Dobrogea, 6\% Bucovina, 6.8\% Moldova, 4\% Maramures, 7.6\% Transilvania, 6\% Crisana and 4.4\% Banat.

\section{Conclusions and recommendation}

The present research is an approach to understanding how the COVID-19 pandemic influenced the entrepreneurial intentions of young people. The study reveals that young people are negatively affected by the pandemic, being undecided when it comes to starting a business. Uncertainty about the future of business and restrictions make young people afraid that if they open a business, they will not make a profit or risk bankruptcy. A percentage of $35.6 \%$ of young people surveyed intended to open a business, and currently $24.4 \%$ are undecided due to fear of failure, and $1.6 \%$ gave up the idea of a business. Most young people, $58.8 \%$ face the lack of funds needed to start a business.

The sectors targeted for starting a business are trade, with a large scale at the moment, tourism, which has a great potential for growth and consulting.

Following the study, the hypothesis that relatives and friends who own a business can positively influence us for future entrepreneurial projects proved to be valid, because after analysing the respondents' answers, it was shown that the $6.4 \%$ who already own a business have relatives. and friends in the entrepreneurial field.

The prospects for the future are generally uncertain, and the duration of the COVID-19 crisis is unclear, people do not know what the business environment will look like after its end. Entrepreneurs are people capable of seeing the opportunity in any chaos. The COVID-19 pandemic must be viewed with optimism and as an opportunity for innovation by all young, future entrepreneurs.

The recommendation for future entrepreneurs is to look around for products and services that will always be sought after by customers. Starting a business during the COVID-19 pandemic may seem impossible, because negative thinking and news influence us, but starting a business right now can be an excellent and wise decision.

This study welcomes young people with business ideas that can be applied in pandemics or can be adapted for existing businesses. From the need of people for interaction, online consulting businesses can take shape, which can be based on various topics, such as: supply chain management, finance, lifestyle, nutrition, birth and breastfeeding, etc. Marketing and graphic design agencies will always be sought after by large companies. Create a digital marketing agency to provide customers with content marketing services, social media, SEO services, paid advertising, analytics, web design and consulting. During the pandemic, people began to focus on fitness and wellness programs, the opening of such a room is appropriate, even if some restrictions do not allow the activity normally, it can work very well in the online environment, where meetings can be organized. fitness.

House cleaning and changing services are highly valued during this period, people being more and more concerned with arranging the house. Even travel agencies can target the online environment. A recommendation for travel agencies would be to make packages for small groups of people or packages for family members and to advise clients online. Pet products and services are in high demand lately. Pet products, such as food and toys, are in high demand right now, so you can channel your love for animals into a pet-friendly business that makes life easier for the consumer. Beauty salons are also businesses that can grow into a pandemic and you can come up with a salon concept that brings specialists to the client's home. These are just some of the things that can grow, you just have to be more optimistic.

If you decide to start a business during a pandemic, it is important to think about its well-being inside. Remote work can become a strategy. Communication remains the key to success, you need to talk to employees daily and hold weekly meetings to discuss goals. Have informal meetings, for example in the morning for coffee or start the workday with team exercises.

Another recommendation is for state institutions and universities, which must be actively involved by supporting young people with entrepreneurial intentions through financial aid programs and their 
promotion. It is particularly important for a young person at the beginning of the road to have a model in front of him and mentors. Thus, it is indicated the involvement of entrepreneurial associations and the organization of information sessions to be attended by people from the business environment, with experience in risk management.

\section{References}

Ahmad, A., F., 2020. Impact of Covid-19 on smes and employment. Entrepreneurship and Sustainability Issues, $8(2)$, pp. 629-648.

Canedo, J., C., Stone, L., D., Black, S., L., Lukaszewski, K., M., 2014. Individual factors affecting entrepreneurship in Hispanics. Journal of Managerial Psychology, 29(6), pp. 755-772. Available at: https://doi.org/10.1108/JMP-11-2012-0333 [accessed 12.03.2021]

Celic, D., Draskovic, Z., Uzelac, Z., Petrov, V., 2018. Differences in attitudes toward internet usage: Empirical study from Serbia. Strategic Management, 23(3), pp. 17-24. Available at: https://pdfs. semanticscholar.org/fb5f/30d52001be6e8a2f9f95c66aa8f6177c5fed.pdf [accessed 12.03.2021]

Craven, M., Liu, L., Mysore, M., Wilson, M., 2020. McKinesy\&Company. Available at: https://www. aedcr.com/sites/default/files/docs/mckinsey-full_article.pdf.pdf.pdf [accessed 15.03.2021]

Dhaliwal, A., 2016. Role Of Entrepreneurship In Economic Development. International Journal of scientific research and management (IJSRM), Volumul 4, pp. 4262-4269.

Fatoki, O., Patswawairi, T., 2012. The motivations and obstacles to immigrant entrepreneurship in South Africa. Journal of Social Science, 32(2), pp. 133-142. Available at: https://www.semanticscholar. org/paper/The-Motivations-and-Obstacles-to-Immigrant-in-South-FatokiPatswawairi/0d6e8795da37a068fc1e8270768383183a369137 [accessed 20.05.2021]

Iakovleva, T., Kolvereid, L., Ute, S., 2011. Entrepreneurial intentions in developing and developed countries. 53(5), pp. 353-370. Available at: https://www.researchgate.net/publication/233951643 Entrepreneurial_Intentions_in_Developing_and_Developed_Countries [accessed 25.03.2021]

Jamali, D., 2009. Constraints and opportunities facing women entrepreneurs in developing countries a relational perspective. Gender in Management: An International Journal, 24(4), p. 232-251. Available at: https://doi.org/10.1108/17542410910961532 [accessed 16.04.2021]

Krueger, N., Reilly, M., Carsrud, A., 2000. Competing models of entrepreneurial intentions. Journal of Business Venturing, 15(5-6), pp. 411-432. Available at: https://www.sciencedirect.com/science /article/abs/pii/S0883902698000330 [accessed 04.04.2021]

Martínez-González, J. A., Kobylinska, U., García-Rodríguez, F., Nazarko, L., 2019. Antecedents of Entrepreneurial Intention among Young People: Model and Regional Evidence. Sustainability. Available at: https://www.researchgate.net/publication/337836063_Antecedents_of_Entrepreneurial _Intention_among_Young_People_Model_and_Regional_Evidence [accessed 20.05.2021]

Monitor, G., 2015. 2014 Global Raport, Available at: https://www.gemconsortium.org/report [accessed 10.03.2021]

Pop, N., 2020. Challenges and Opportunities to Develop Organizations Through Creativity, Technology and Ethics. s.l.:Springer. Available at: https://www.researchgate.net/publication/342100809_ Contemporary_Directions_in_the_Development_of_Romanian_Academic_Marketing_in_Favor_of_I ncreasing_the_Performance_of_the_Organization [accessed 14.03.2021]

Solesvik, M., Westhead, P., Kolvereid, L., Matlay, H., 2012. Student intentions to become self-employed: the Ukrainian context. Journal of small business and enterprise development, 19(3), pp. 441-460. Available at: https://www.researchgate.net/publication/235306424_Student_intentions_to_become_selfemployed_The_Ukrainian_context [accessed 25.03.2021]

Toma, S., G., Grigore, A., M., Marinescu, P., 2014. Economic development and entrepreneurship. ScienceDirect, Volumul 8, pp. 436-443. Available at: https://www.sciencedirect.com/science/article/pii/ S2212567114001117 [accessed 10.03.2021]

Thompson, E., R., 2009. Individual Entrepreneurial Intent: Construct Clarification and Development of an Internationally Reliable Metric. Entrepreneurship Theory and Practice, 33(3), pp. 669-694. Available at: https://www.emerald.com/insight/content/doi/10.1108/JSBED-07-2019-0241/full/html [accessed 22.03.2021]

Verheul, I., Thurik, R., Hessels, J., Zwan, P., 2010. Factors influencing the entrepreneurial engagement of opportunity and necessity entrepreneurs. Eurasian Economic Review, pp. 1-24. Available at: https://www.researchgate.net/publication/46455747_Factors_Influencing_the_Entrepreneurial_Engag ement_of_Opportunity_and_Necessity_Entrepreneurs [accessed 04.04.2021]

Zacks Equity Research, 2020.Available at: https://www.nasdaq.com/articles/activision-blizzard-walt-disneyamazon-alphabet-and-microsoft-highlighted-as-zacks-bull [accessed 12.04.2021] 